\title{
Perspectives on The Techno-Economic Analysis of Carbon Capture and Storage
}

\author{
Simon P Philbin ${ }^{1^{*}}$, Steve Hsueh-Ming Wang ${ }^{2}$
}

\begin{abstract}
Carbon capture and storage (CCS) is required in order to reduce the impact of fossil fuel burning on global warming and the resulting climate change. The use of CCS technology offers much promise in regard to the capture of major levels of waste carbon dioxide produced from the burning of fossil fuels for electricity generation and from industrial processes. Crucial to the development of CCS technology is the need for improved decision-making tools to underpin sustainable investment and associated policy initiatives for CCS technology and infrastructure. Consequently, this paper provides the results from the techno-economic analysis of CCS. This includes regression modelling of the levelized cost of electricity for power generation via combined cycle gas turbine both with and without CCS. In order to inform future research in the area, a supporting CCS research agenda has been formulated.
\end{abstract}

Keywords: carbon capture and storage (CCS); techno-economic analysis; sustainable development; policy framework; decision-making

Submitted: Jun $9^{\text {th }}, 2019$ / Approved: Sep $9^{\text {th }}, 2019$

\section{Introduction}

The use of carbon capture and storage (CCS) technology offers much promise in regard to the capture of major levels of waste carbon dioxide $\left(\mathrm{CO}_{2}\right)$ produced from the burning of fossil fuels for electricity generation and from industrial activities (Metz et al., 2005). This is required in order to reduce the impact of fossil fuel burning on global warming and the resulting climate change. Indeed, CCS technology is poised to play a significant part in helping nations to meet the obligations set out in the Paris Climate Conference of December 2015 (Cornwall, 2015), where 195 countries adopted a legally binding agreement and action plan to work towards limiting global warming to well below $2^{\circ} \mathrm{C}$. Moreover, the impacts of global warming of $1.5^{\circ} \mathrm{C}$ above pre-industrial levels have recently been highlighted (IPCC, 2018), which has underlined the need for action on this matter. Although CCS technology has to date not been able to reach a level of industrial development that was envisaged a decade ago and there remain a number of technical and commercial challenges to be addressed for the technology to be successfully deployed on an industrial scale (Bui et al., 2018), it does nevertheless provide a viable route to minimize net $\mathrm{CO}_{2}$ emissions.

In the CCS process, carbon dioxide is captured from power plants or industrial facilities, transported to an appropriate storage site and finally the carbon dioxide is deposited in a long-term storage medium, such as a geological formation, so that it will not enter the atmosphere. Although carbon dioxide has been injected into rock formations for many years as part of enhanced oil recovery (EOR), it is still a relatively new approach for storing carbon dioxide produced by power plants in order to reduce carbon dioxide levels in the atmosphere and mitigate the effects of global warming (Benson and Cole, 2008). In regard to the CCS options for natural gas and coal there are primarily three processes available to capture the carbon dioxide generated by combustion of these fossil fuels. These are post-combustion, pre-combustion and oxy-fuel capture systems (Kunze and Spliethoff, 2012). Implementation of these technologies will depend on a number of technological and process engineering factors that need to be investigated further.

The technology to enable capture and storage of carbon dioxide has been under development for several years (Figueroa et al., 2008) and a number of CCS projects are now online with more facilities to be established in the future. In addition to the development of commercial and industrial scale plants (Global CCS Institute, 2017), there are a number of technology demonstration and pilot scale facilities around the world (Global CCS Institute, 2016). There are also supporting feasibility and other studies that have been undertaken to investigate CCS technology applications as well as the commercial case for investment in CCS infrastructure. For an example techno-economic study for CCS technology implementation, see the work of Nakaten et al. (2014) in regard to calculating the cost of electricity, energy demand and $\mathrm{CO}_{2}$ emissions of an integrated UCG (underground coal gasification)-CCS process.

Although there are various CCS projects that have been commissioned there remain significant challenges that still need to be overcome, including technological, economic and environmental issues (Pires et al., 2011) as well as the need for effective engagement with societal groups on the benefits of CCS adoption and mitigation of the perceived risks of implementing the technology. Nevertheless, CCS projects offer much potential and there is also the scope for an entire new CCS industry and corresponding industrial supply chain to be created as the projects are delivered globally (Haszeldine, 2009). Consequently, it is appropriate to consider investment decisions for CCS facilities and underpinning technologies from a sustainability perspective, which needs to integrate environmental, social and economic interests to yield effective business strategies (Schwarz, Beloff, and Beaver, 2002).

1) Nathu Puri Institute for Engineering and Enterprise, London South Bank University, United Kingdom.

2) Sichuan University-Pittsburgh Institute (SCUPI), China.

*Corresponding author: philbins@lsbu.ac.uk. 
This this paper will provide the results from the techno-economic analysis of carbon capture and storage technologies. This analysis includes consideration of a range of different supporting areas or themes, namely CCS technologies and investment levels; CCS policy determinants (regulatory and environmental, economic and technological aspects); economic analysis of CCS with LCOE (levelized cost of electricity); and the review of data on CCS pilot-scale projects. In order to inform future research studies in the area, a CCS research agenda has also been formulated.

\section{Methodology}

The methodology adopted in this research study was to consider the technological and economic aspects of carbon capture and storage according to four main areas or themes, which are summarized in Figure 1. The method is based on techno-economic analysis of available data relating to the adoption of CCS technologies and also the sustainability of the process from an economic perspective. Techno-economic analysis is a recognized method for analyzing complex situations and enabling the resulting synthesis of evidence-based findings. For example, see the work of Zoulias and Lymberopoulos (2007) on the integration of hydrogen energy technologies with renewable energy-based stand-alone power systems, and Yang et al. (2009) on the design of a hybrid solar-wind power generation system. Furthermore, technoeconomic analysis can be considered as being complementary to other technology evaluation approaches, such as technology forecasting (Philbin, 2013).

Figure 1. Schematic view of the research methodology and main themes of the techno-economic analysis of CCS.

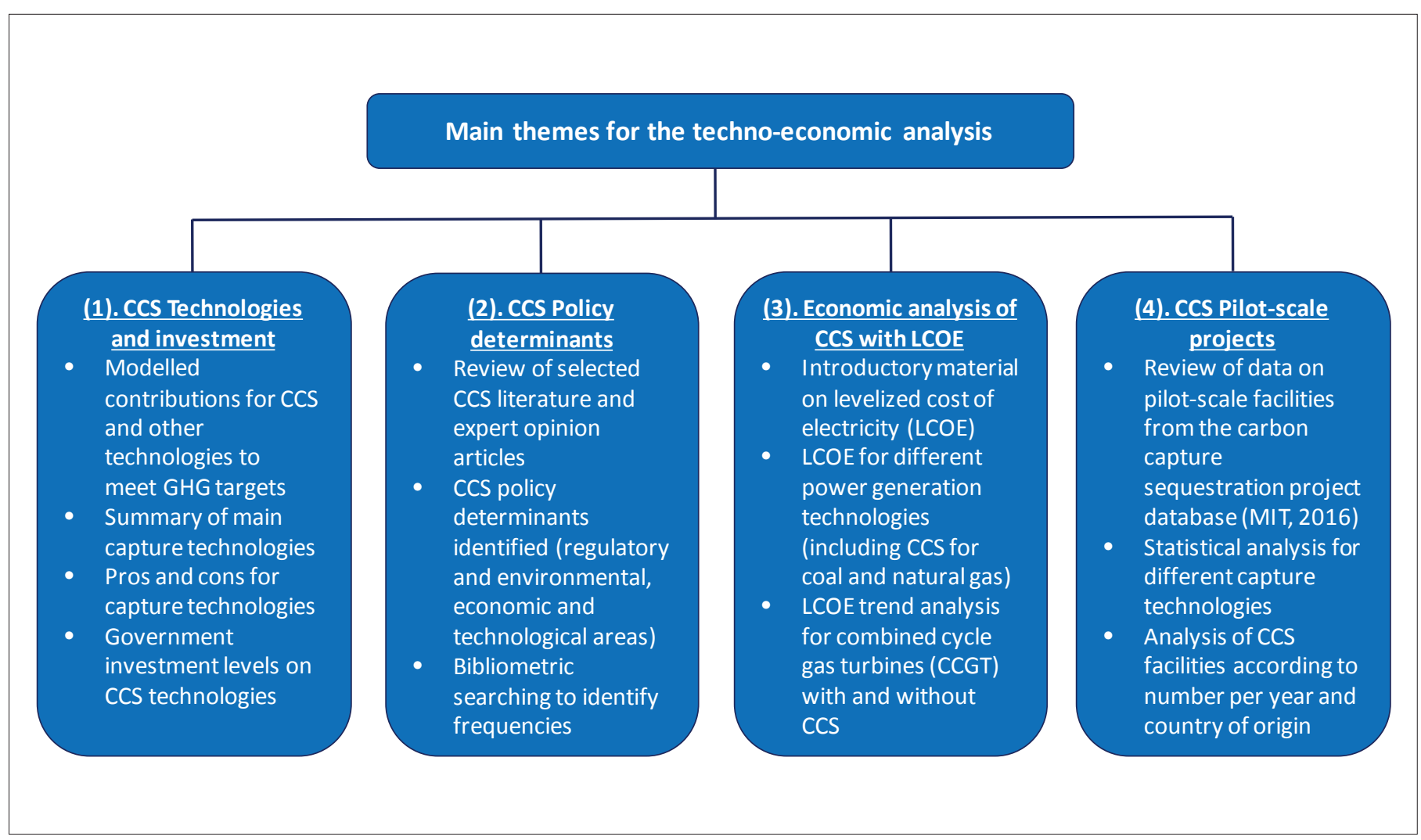

\section{Techno-economic analysis of carbon capture and storage}

\section{CCS technologies and investment}

The implementation of CCS technology has the capacity to be an important component in regard to international efforts to limit greenhouse gas (GHG) emissions. Indeed, the International Energy Agency (IEA, 2015) has modelled that CCS could potentially drive $13 \%$ of the cumulative emissions reductions that are required by 2050 in order to limit the global increase in temperature to $2^{\circ} \mathrm{C}$ (see Figure 2). This would represent the capture and storage of approximately 6 billion tonnes (Bt.) of $\mathrm{CO}_{2}$ emissions per year in 2050. 
Figure 2. Modelled contributions from different technologies and sectors to meet required global cumulative $\mathrm{CO}_{2}$ reductions (source: IEA, 2015).

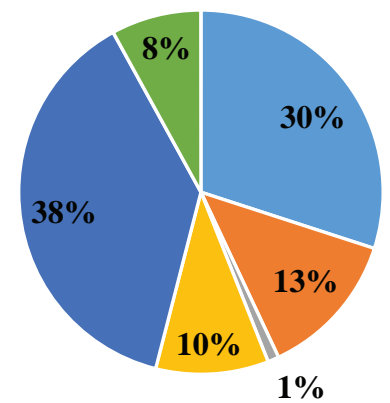

\section{Renewables \\ $\square$ CCS \\ - Power generation efficiency and fuel switching \\ End-use fuel switching \\ - End-use fuel and electricity efficiency \\ - Nuclear}

This highlights the role that CCS can play alongside various carbon mitigation strategies, such as an increasing adoption of renewables, nuclear power generation as well as other power generation and fuel usage approaches. There are three core technologies (Kanniche et al., 2010) that are available to support the capture of $\mathrm{CO}_{2}$ and these are as follows:

- $\quad$ Pre-combustion capture: This involves gasification of the fuel (typically coal) to produce a synthesis gas, whereupon after further conversion the $\mathrm{CO}_{2}$ is removed followed by combustion. There is growing interest in IGCC (integrated gasification combined cycle applications) as a pre-combustion CCS technology.

- $\quad$ Post-combustion capture: This involves capture of $\mathrm{CO}_{2}$ through separating from the combustion gases after the fuel has been burned. The $\mathrm{CO}_{2}$ is captured from the combustion gas through an appropriate method, such as being absorbed in a solvent, membrane separation or cryogenic separation. Once the $\mathrm{CO}_{2}$ has been extracted it is compressed and either transported or stored, as appropriate.

- Oxy-fuel capture: This involves combustion in oxygen along with recycling of the exhaust gases that are composed principally of $\mathrm{CO}$ (carbon monoxide) and water, followed by purification of the CO flow to eliminate incondensable gases.

In order to highlight some of the key differences between these three core capture technologies, the advantages and disadvantages can be considered, which are summarized in Table 1.

Table 1. Advantages and disadvantages for $\mathrm{CO}_{2}$ capture technologies (source: Figueroa et al., 2008).

\begin{tabular}{|c|c|c|}
\hline Technology & Advantages & Disadvantages \\
\hline Pre-combustion capture & $\begin{array}{l}\text { Synthesis gas is both high pressure and with high } \mathrm{CO}_{2} \\
\text { concentrations. } \\
\text { Various technology options available to enable separation. } \\
\text { Gasification is a recognized process. }\end{array}$ & $\begin{array}{l}\text { Equipment potentially expensive. } \\
\text { Supporting systems are needed. } \\
\text { Application more towards new build facilities and not existing } \\
\text { plants. }\end{array}$ \\
\hline Oxy-fuel capture & $\begin{array}{l}\text { Very high concentrations of } \mathrm{CO}_{2} \text { in flue gas. } \\
\text { Retrofit technology options available. }\end{array}$ & $\begin{array}{l}\text { Less advanced technology base when compared to pre- and post- } \\
\text { combustion. } \\
\text { Equipment cost base could be high. } \\
\text { Process efficiency not optimized. }\end{array}$ \\
\hline
\end{tabular}


As can be ascertained, each capture technology has its own pros and cons, although on balance it is recognized that post-combustion capture technology is currently the most promising technology to reduce $\mathrm{CO}_{2}$ emissions from the conversion of fossil fuels as sources of energy (Anthony and Clough, 2019). Moreover, we can consider the cumulative growth in storage capacity for operational and planned CCS facilities (Global CCS Institute, 2017) in Mtpa (million metric tonnes per annum) and it can be observed that storage capacity has grown considerable since around the year 2000 (see Figure 3). The data shows that since the first CCS facility opened in 1972 (Val Verde Natural Gas
Plant in USA, which is an EOR facility with a capacity of $1.3 \mathrm{Mtpa}$ ), capacity had grown to ca. 13 Mtpa in 2000. The global capacity grew further to 31 Mtpa by early 2017, with a further expected increase to 41 Mtpa by the end of 2017 assuming all the scheduled CCS facilities come online that year. This rate of growth in capacity highlights the increasing rate of adoption of CCS technologies along with a rapidly increasing level of global $\mathrm{CO}_{2}$ storage capacity. There is no reason to currently suggest this increase will not continue as CCS technologies are further proven and as more CCS projects are commissioned beyond the 2017-2019 period.

Figure 3. Cumulative increase in storage capacity (Mtpa) for operational and planned CCS facilities - based on data from the Global CCS Institute (2017).

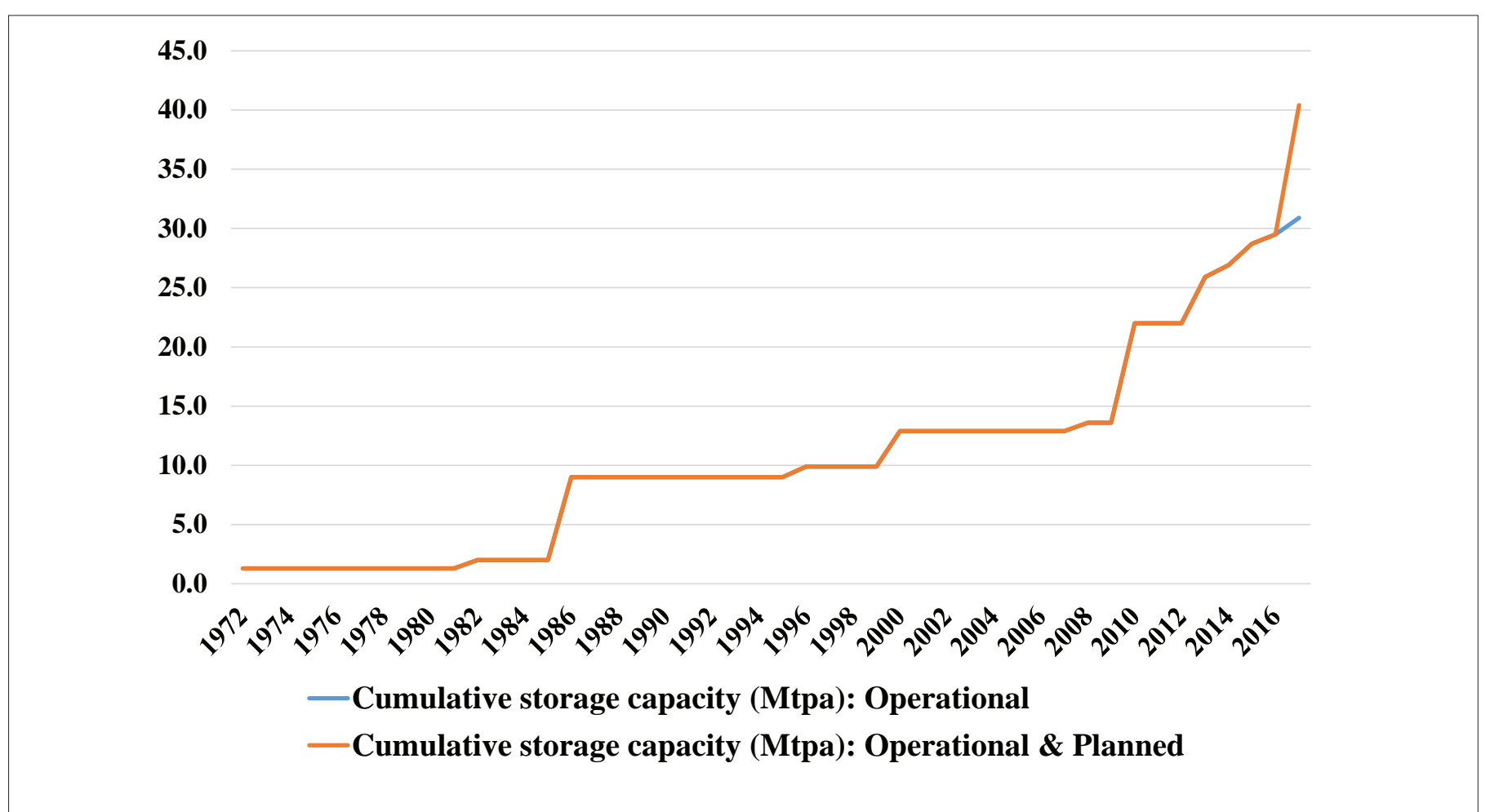

On the matter of governmental level investment in CCS technologies, a range of projects have been supported by the United States (US) Department of Energy (United States Department of Energy, 2019). This includes investment in post-combustion and pre-combustion CCS technology projects, with a total investment of USD $\$ 83.8 \mathrm{mi}-$ llion across 18 projects. This includes USD \$71.5million (85\%, N $=15$ projects) invested on post-combustion technologies and USD $\$ 12.3$ million ( $15 \%, \mathrm{~N}=3$ projects) invested on pre-combustion technologies, and the current preference to financially support postcombustion technologies can be observed from this data.

The post-combustion technologies supported by the US Department of Energy include a range of areas, such as $\mathrm{CO}_{2}$ sorbent capture process, solvent-based technology to extract $\mathrm{CO}_{2}$, hybrid membraneabsorption $\mathrm{CO}_{2}$ capture system as well as various other solvent and membrane separation technologies. The pre-combustion technologies supported include membrane-based $\mathrm{CO}_{2}$ capture processes, and sorbent-based carbon capture system. Investment into these CCS technology projects highlights the level of interest in certain core technology areas, namely membrane and solvent-based $\mathrm{CO}_{2}$ capture systems and the associated engineering and process aspects. It is envisaged that continued investment is required in these underpinning areas in order to improve engineering efficiencies as well as cost reductions for the technology implementation as part of both postcombustion and pre-combustion large-scale CCS facilities.

\section{CCS policy determinants}

Investment into CCS technologies and projects, including pilot scale as well as larger operational scale plants can be influenced by a range of factors, which includes regulatory and environmental, economic as well as technological factors. Sustainable development should take account of the need for integration across social, economic and ecological perspectives (Gibson, 2006). Indeed, the development of CCS technologies and corresponding power generation systems is a 
complex matter and the supporting policy frameworks for such implementations need to be carefully developed through taking account of different stakeholder perspectives. Furthermore, we can consider these factors as determinants of CCS policy and it is therefore useful to review the literature in a rigorous manner in order to derive the main CCS policy determinants according to these three areas. In a re- lated approach, dos Santos et al. (2014) reviewed literature sources in order to map the sustainable structural dimensions for managing the biodiesel supply chain in Brazil. Consequently, Table 2 provides the results from the review of selected literature and expert opinion based publications on CCS in order to establish the main policy-based decision factors associated with implementation of CCS.

Table 2. Findings from review and analysis of expert opinion based studies from the literature.

\begin{tabular}{ll}
\hline Main findings & Reference \\
\hline $\begin{array}{l}\text { Research study identified two barriers to the deployment of CCS technologies, which are as follows: A need for appropriate fun- } \\
\text { ding mechanisms that are sufficiently large and long-term; legal and regulatory frameworks designed for the transport and geolo- } \\
\text { gical storage of carbon dioxide. }\end{array}$ & $\begin{array}{l}\text { Gibbins } \\
2008\end{array}$ \\
\end{tabular}

Report described six main CCS components, which are as follows: Capture, transportation, geological storage, ocean storage, mineral carbonation, and industrial uses of carbon dioxide.

Metz et al., 2005

This research identified seven key uncertainties for CCS deployment, which are as follows: Variety of pathways; safe storage, scaling up, speed of development \& deployment; integration of CCS systems, economic and financial viability; policy, political \& regulatory uncertainty; public acceptance. Additionally, inter-linkages between the uncertainties were identified, which are as follows: regulatory uncertainty; public support for policy \& regulation for confidence, selective opposition, lock-in versus diversity; risk perception; a top-down push for speed; design consensus; learning by doing; business models \& costs of learning to organize; electricity bills; liabilities.

Review of research concentrated on opportunities for carbon dioxide capture (electric power generation and industry), carbon dioxide transportation and storage (transportation, geologic storage and ocean storage), and other considerations (direct use, conversion to carbonates, biological conversion to fuels, regulatory issues and leakage, carbon capture and storage cost modeling for electricity generation).

Survey based research identified a number of potential show stoppers that could prevent implementation of CCS in the united Kingdom, which are as follows: lack of long-term policy framework; costs; international regulatory framework; public opinion; technical and engineering challenges; leakage of stored carbon dioxide; environmental impacts; unsatisfactory verification methods; NGO (non-governmental organizations) responses; ineffectiveness as a mitigation option; inadequate monitoring methods; skills shortage; other (cooperation).

Review of carbon capture and storage, which is viewed as a bridging technology to a sustainable energy production and its largescale deployment depends on technological advances and social processes. In this context, public perception is viewed as being of paramount importance to implementation of CCS technologies.

Selma et al., 2014

Review that described how the commercialization of CCS depends on many technological, commercial, and political hurdles to be overcome in regard to carbon capture, transportation of liquefied carbon dioxide and its storage in exploited oil fields or saline Haszeldine, 2009 formations.

Review of key CCS processes, which are as follows: chemical absorption, physical absorption, physical adsorption, membrane separation, compression and pumping, condensation and liquefaction, pipeline transport, ship transport, geological storage, and ocean storage.

Review of carbon dioxide sequestration in deep sedimentary formations that elucidated the need for rigorous scientific studies on the coupled hydrologic-geochemical-geo-mechanical processes that govern the long-term fate of carbon dioxide in the subsurface. The study also identified the need for methods designed to characterize and select sequestration sites as well as sub-surface engineering to optimize performance and cost, safe operational processes, monitoring technology, remediation methods, regulatory oversight mechanisms, and institutional approaches designed for managing long-term liabilities. 
Consideration of the findings from the literature allows the CCS policy determinants to be synthesized according to the three main areas and they are as follows:

- Regulatory and environmental factors: Regulatory framework (no. 01), site selection (no. 02), public awareness (no. 03), and environmental assessment (no. 04).

- Economic factors: Cost reduction (no. 05), government funding (no. 06), investment decision (no. 07), and international collaboration (no. 08).

- Technological factors: Capture technology (no. 09), storage technology (no. 10), transportation system (no. 11), and monitoring technology (no. 12).
Bibliometric analysis has been undertaken in order to derive the relative weightings for these decision factors and the structured literature search was carried out on $13^{\text {th }}$ April 2019 using the ScienceDirect online database, which specializes in scientific, engineering, and medical research. Publications searched include review articles, research articles, book chapters, and conference abstracts. The search was restricted to publications from 2014 onwards, thereby providing a minimum of 5 years of publications' data that is up-to-date. The results from the literature review according to the key decision factors is provided in Table 3.

Table 3. Results from structured literature review according to the key decisions factors contributing to sustainable policy for CCS investment decisions.

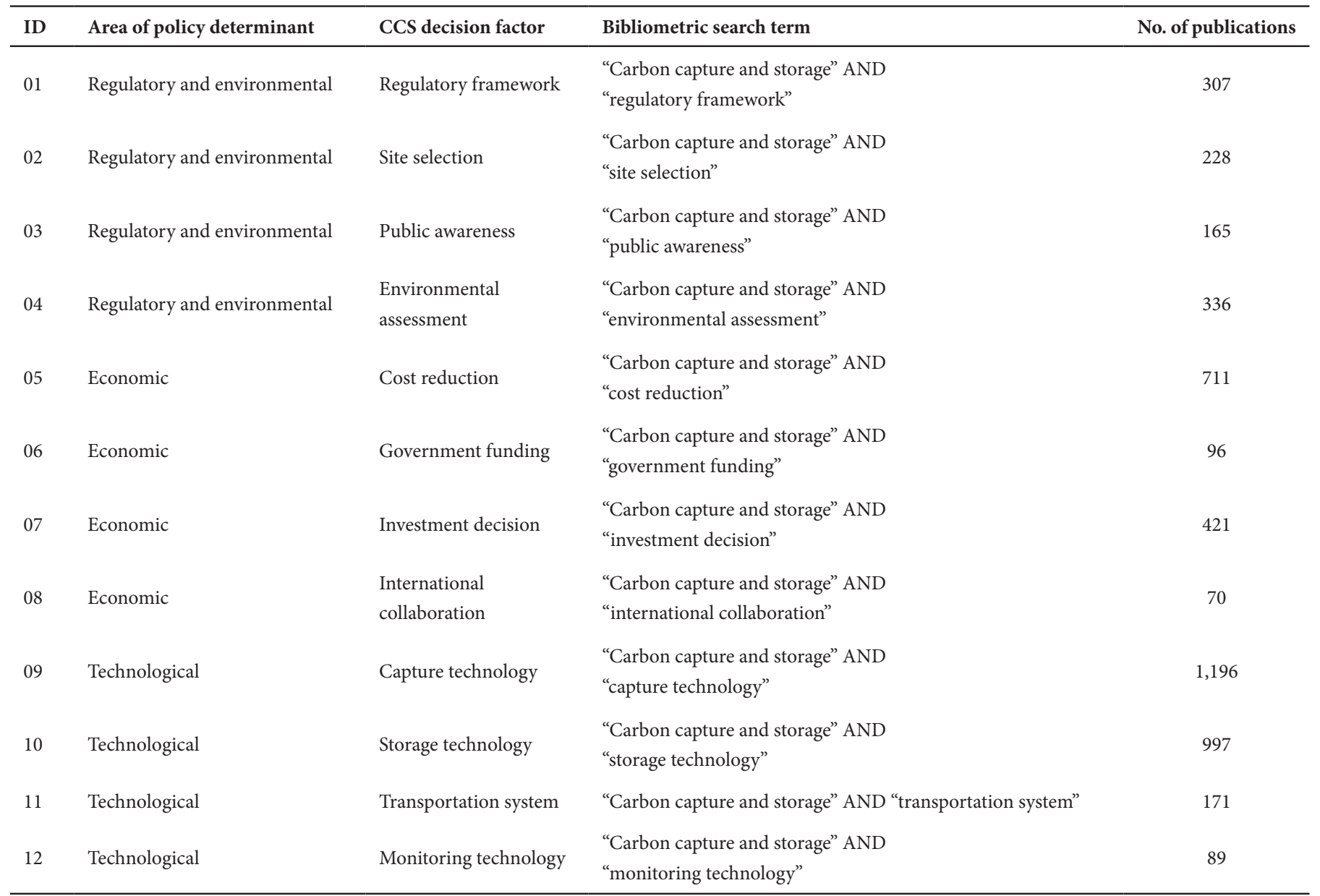

We can observe from the results from the structured literature search (Figure 4) that the CCS decision factors with the highest frequency are capture technology $(\mathrm{N}=1,196)$, storage technology $(\mathrm{N}=997)$, and cost reduction $(\mathrm{N}=711)$. Mid-level frequencies include investment decision $(\mathrm{N}=421)$, environmental assessment $(\mathrm{N}=$ $336)$, regulatory framework $(\mathrm{N}=307)$, and site selection $(\mathrm{N}=228)$.
Low-level frequencies are transportation system $(\mathrm{N}=171)$, public awareness $(\mathrm{N}=165)$, government funding $(\mathrm{N}=96)$, monitoring technology $(\mathrm{N}=89)$, and international collaboration $(\mathrm{N}=70)$. These frequencies provide an indication of the relative importance (and weighting) of such factors in regard to policy and investment decisions for CCS technologies. 
Figure 4. Frequency of the CCS decision factors ascertained through structured literature review.

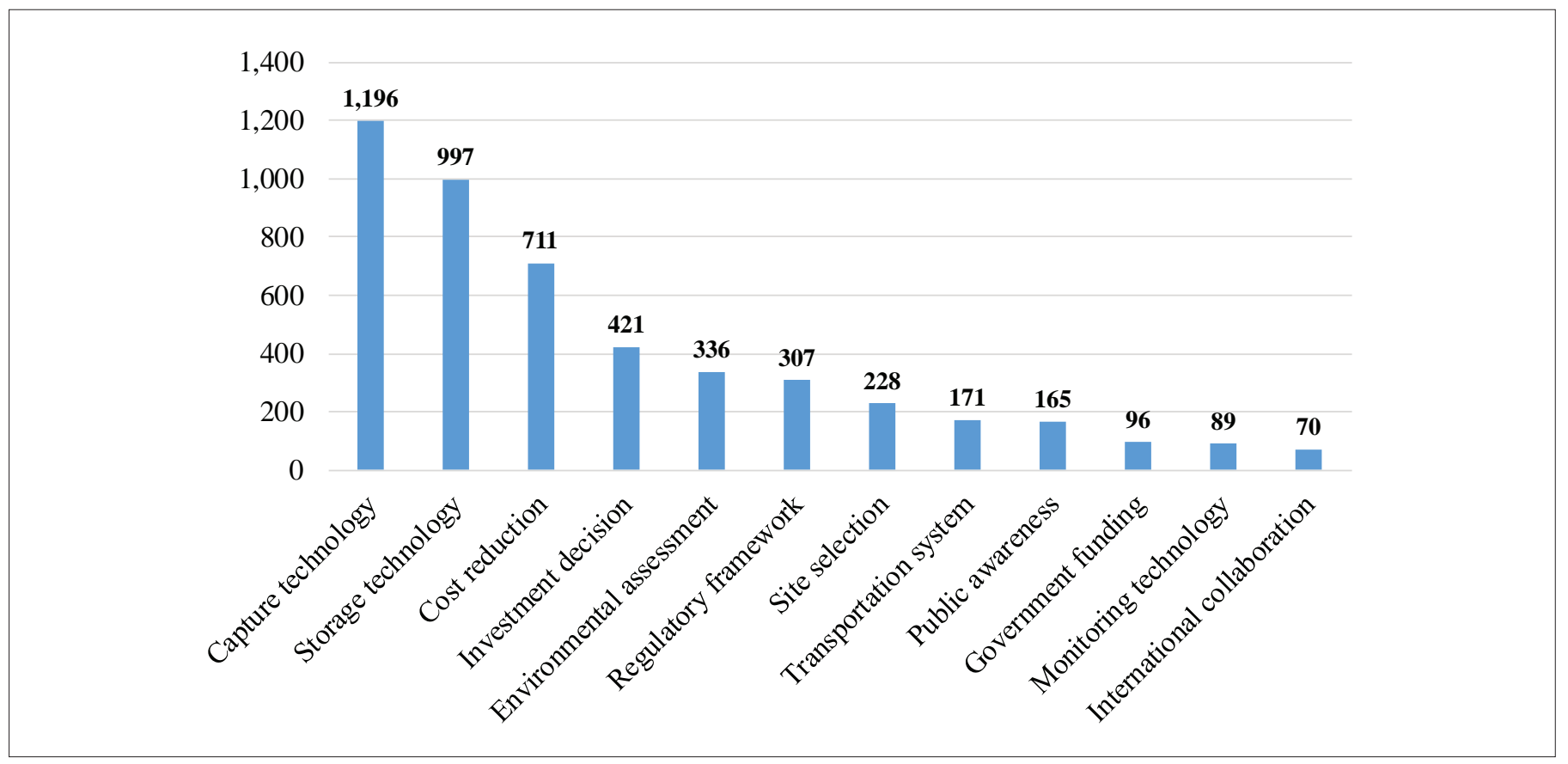

\section{Economic analysis of CCS with LCOE}

Levelized cost of electricity (LCOE) is a numerical measure that is calculated in order to assess the commercial case for power generation technologies (Irlam, 2015). The LCOE approach is based on calculating the present value of costs per unit of electricity that is generated over the life of a specific power plant. A comprehensive treatment of LCOE is provided by Short et al. (2005). In high level terms, LCOE can be viewed as a long-term cost measure that takes account of the total life cycle cost and the total lifetime energy production (see Figure 5).

Figure 5. Levelized cost of electricity calculation.

LCOE $=\frac{\text { Total life cycle cost }}{\text { Total lifetime energy production }}$

LCOE takes account of the number of hours per year that a power generation facility can operate, fuel costs and the corresponding fuel efficiency as well as the power plant life of operation as well as construction factors, such as construction schedule. Data has been assembled by the Global CCS Institute (Irlam, 2015), which provides a comparison of the LCOE for different power generation technologies including data for non-CCS and CCS variants of gas fired and coal fired power generation plants (see Figure 6).
Figure 6. Levelized cost of electricity, LCOE (2014 USD \$) for power generation technologies in the United States. Source: Global CCS Institute (Irlam, 2015).

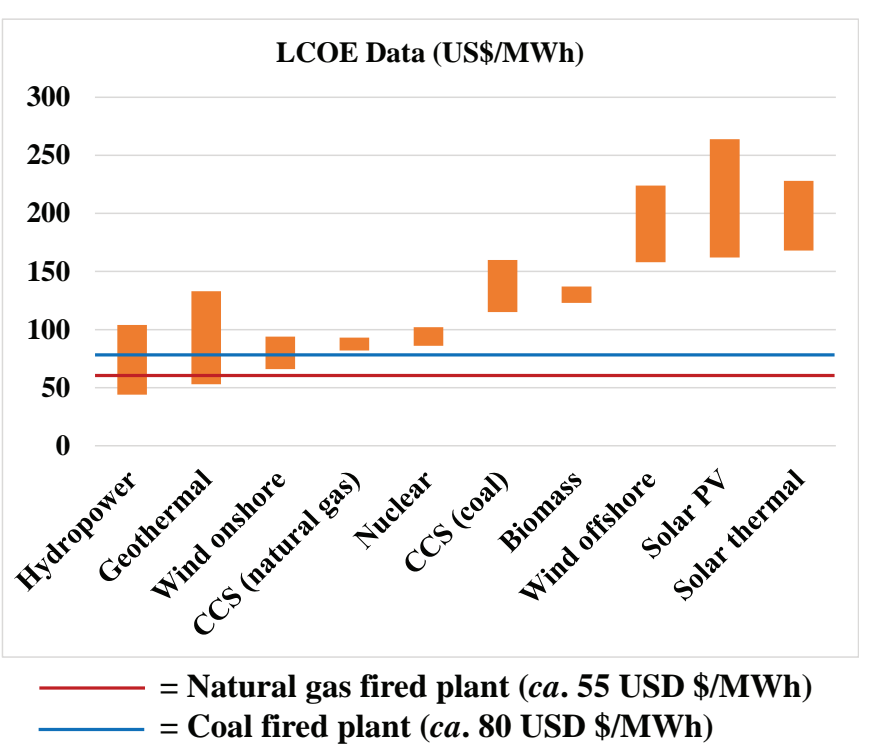

In the case of traditional natural gas fired plants, the LCOE is $c a .55$ USD \$/MWh, whereas the CCS variant has a LCOE of 82-93 USD \$/ MWh, i.e. representing a cost premium of $c a .30$ USD \$/MWh for CCS adoption to natural gas fired plants. Additionally, in the case of traditional coal fired plants, the LCOE is $c a$. 80 USD \$/MWh, whereas the CCS variant has a LCOE of 115-160 USD \$/MWh, i.e. representing a cost premium of $c a .60$ USD \$/MWh for CCS adoption to coal fired plants. It should be noted the range of LCOE values represents the sensitivity of the data. 
LCOE allows comparison of different forms of power generation and this data shows that while application of CCS technology to existing fossil fuel burning plants does add a cost premium to the LCOE, it does nevertheless compare favorably with some other forms of power generation. For instance, CCS (natural gas) has an estimated LCOE of 82-93 USD \$/MWh, whereas various renewable technologies have the following estimated LCOE ranges (allowing for sensitivities): wind offshore (158-224 USD \$/MWh), solar PV (158-224 USD \$/ $\mathrm{MWh}$ ), and solar thermal (168-228 USD \$/MWh). Consequently, adoption of CCS technology for fossil fuel burning plants does appear to be affordable (and especially for natural gas power generation) when compared to certain renewable energy options.

In order to focus on LCOE trend analysis, we can consider the case for Combined Cycle Gas Turbines (CCGT). These forms of power generation are based on a gas-fired turbine combined with a steam turbine (Horlock, 1992). This technology is based on the use of a gas turbine to generate electricity with the waste heat that is generated used to produce steam, which then drives a further steam turbine thereby increasing the level of power generation that is achieved by the system. Figure 7 provides LCOE trend analysis for CCGT power generation systems both with CCS and without CCS (sources of data: ETI, 2012; Irlam, 2015; Gammer, 2016; EIA, 2018). Based on regression analysis we can see that there is a trend towards both systems having lower costs, with CCGT fitted with CCS $\left(\mathrm{R}^{2}=0.8862\right)$ expected to have a lower LCOE in $2022\left(\mathrm{R}^{2}=\right.$ 0.9098), when compared to conventional CCGT without CCS in 2012. This trend indicates a potentially improving economic position for the adoption of CCS technology for the application of power generation via CCGT.

Figure 7. LCOE trend analysis for CCGT with and without CCS (sources of data: ETI, 2012; Irlam, 2015; Gammer, 2016; EIA, 2018)

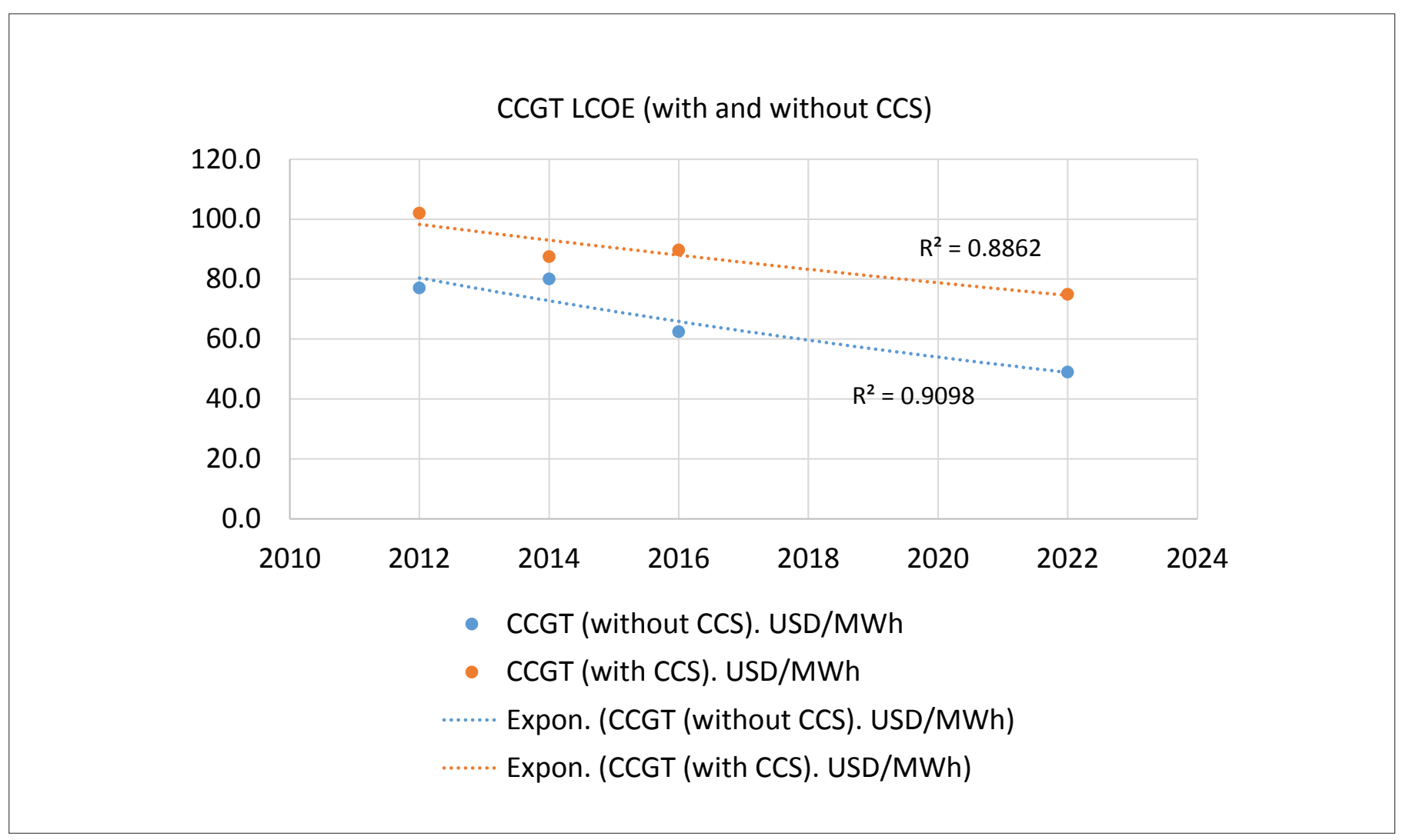

\section{CCS pilot scale projects}

Various data is available from the Carbon Capture Sequestration project database provided by the Carbon Capture and Sequestration Technologies Group at Massachusetts Institute of Technology, USA
(MIT, 2016) and this includes data on pilot-scale CCS projects. It is useful to review this data and Table 4 provides a summary of the data for various plants where capacity levels are shown in MW, and Table 5 provides further data on other plants where the capacity data is in $\mathrm{Mt} / \mathrm{yr}$. 
Table 4. Summary of pilot-scale CCS projects with capacity data given in MW. Source of data: Carbon Capture and Sequestration Technologies Group at Massachusetts Institute of Technology, USA (MIT, 2016).

\begin{tabular}{|c|c|c|c|c|c|c|c|c|}
\hline Project Name & Leader & Location & Feedstock & $\begin{array}{c}\text { Size } \\
(\mathrm{MW})\end{array}$ & $\begin{array}{l}\text { Capture } \\
\text { Process }\end{array}$ & CO2 Fate & $\begin{array}{c}\text { Year } \\
\text { Operational } \\
\end{array}$ & $\begin{array}{c}\text { Completed or } \\
\text { Operating } \\
\end{array}$ \\
\hline Schwarze Pumpe & Vattenfall & Germany & Coal & 30 & Oxyfuel & Depleted Gas & 2008 & Completed \\
\hline ECO2 Burger & Powerspan & USA & Coal & 1 & $\begin{array}{l}\text { Post- } \\
\text { Combustion }\end{array}$ & Vented & 2008 & Completed \\
\hline Pleasant Prairie & Alstom & USA & Coal & 5 & $\begin{array}{l}\text { Post- } \\
\text { Combustion }\end{array}$ & Vented & 2008 & Completed \\
\hline $\begin{array}{l}\text { AEP } \\
\text { Mountaineer }\end{array}$ & AEP & USA & Coal & 30 & $\begin{array}{l}\text { Post- } \\
\text { Combustion }\end{array}$ & Saline & 2009 & Completed \\
\hline Karlshamn & E.ON & Sweden & Oil & 5 & $\begin{array}{l}\text { Post- } \\
\text { Combustion }\end{array}$ & Vented & 2009 & Completed \\
\hline Compostilla & ENDESA & Spain & Coal & 30 & Oxyfuel & Saline & 2009 & Completed \\
\hline Puertollano & ELCOGAS & Spain & Coal & 14 & $\begin{array}{l}\text { Pre- } \\
\text { Combustion }\end{array}$ & Recycled & 2010 & Completed \\
\hline Lacq & Total & France & Oil & 35 & Oxyfuel & Depleted Gas & 2010 & Completed \\
\hline Buggenum & Vattenfall & Netherlands & Coal & 20 & $\begin{array}{l}\text { Pre- } \\
\text { Combustion }\end{array}$ & Vented & 2011 & Completed \\
\hline Brindisi & Enel \&Eni & Italy & Coal & 48 & $\begin{array}{l}\text { Post- } \\
\text { Combustion }\end{array}$ & EOR & 2011 & Completed \\
\hline $\begin{array}{l}\text { Ferrybridge } \\
\text { CCSPilot100+ }\end{array}$ & SSE & UK & Coal & 5 & $\begin{array}{l}\text { Post- } \\
\text { Combustion }\end{array}$ & Vented & 2012 & Completed \\
\hline Aberthaw & RWE & UK & Coal & 3 & $\begin{array}{l}\text { Post- } \\
\text { Combustion }\end{array}$ & N/A & 2013 & Completed \\
\hline $\begin{array}{l}\text { Callide-A Oxy } \\
\text { Fuel }\end{array}$ & CS Energy & Australia & Coal & 30 & Oxyfuel & Saline & 2012 & Completed \\
\hline Ordos & Shenhua group & China & Liquefaction & 0.1 & $\begin{array}{l}\text { Post- } \\
\text { Combustion }\end{array}$ & EOR / Saline & 2011 & Operating \\
\hline Wilhelmshaven & E.ON & Germany & Coal & 3.5 & $\begin{array}{l}\text { Post- } \\
\text { Combustion }\end{array}$ & Vented & 2012 & Operating \\
\hline Plant Barry & $\begin{array}{l}\text { Southern } \\
\text { Energy }\end{array}$ & USA & Coal & 25 & $\begin{array}{l}\text { Post- } \\
\text { Combustion }\end{array}$ & Saline & 2011 & Operating \\
\hline Boryeong Station & KEPCO & South Korea & Coal & 10 & $\begin{array}{l}\text { Post- } \\
\text { Combustion }\end{array}$ & Vented & 2013 & Operating \\
\hline
\end{tabular}


Table 5. Summary of pilot-scale CCS projects with capacity data given in Mt/yr. Source of data: Carbon Capture and Sequestration Technologies Group at Massachusetts Institute of Technology, USA (MIT, 2016).

\begin{tabular}{|c|c|c|c|c|c|c|c|c|}
\hline $\begin{array}{l}\text { Project } \\
\text { Name }\end{array}$ & Leader & Location & Feedstock & $\begin{array}{c}\text { Size } \\
(\mathrm{Mt} / \mathrm{yr})\end{array}$ & $\begin{array}{l}\text { Capture } \\
\text { Process }\end{array}$ & CO2 Fate & $\begin{array}{c}\text { Year } \\
\text { Operational }\end{array}$ & $\begin{array}{c}\text { Completed or } \\
\text { Operating }\end{array}$ \\
\hline K12-B & GDF Suez & Netherlands & Gas Processing & 0.2 & Depleted Gas & 2004 & 2004 & Completed \\
\hline Ketzin & GFZ & Germany & H2 Production & 0.06 & $\begin{array}{l}\text { Post- } \\
\text { Combustion }\end{array}$ & Saline & 2008 & Completed \\
\hline Otway & CO2CRC & Australia & Natural Deposit & 0.065 & Natural Deposit & Depleted Gas & 2008 & Completed \\
\hline Polk & $\begin{array}{l}\text { Tampa } \\
\text { Electric }\end{array}$ & USA & Coal & 0.3 & Pre-Combustion & Saline & 2014 & Completed \\
\hline Zama & $\begin{array}{l}\text { Apache \& } \\
\text { PCOR }\end{array}$ & Canada & Gas Processing & 0.026 & Gas Production & EOR & 2006 & Operating \\
\hline Snohvit & StatoilHydro & Norway & $\begin{array}{l}\text { LNG } \\
\text { Processing }\end{array}$ & 0.7 & $\begin{array}{l}\text { Post- } \\
\text { Combustion }\end{array}$ & Saline & 2007 & Operating \\
\hline Shidongkou & Huaneng & China & Coal & 0.1 & $\begin{array}{l}\text { Post- } \\
\text { Combustion }\end{array}$ & $\begin{array}{l}\text { Commercial } \\
\text { Use }\end{array}$ & 2009 & Operating \\
\hline Jilin & PetroChina & China & $\begin{array}{l}\text { Nat. Gas } \\
\text { Processing }\end{array}$ & 0.2 & $\begin{array}{l}\text { Post- } \\
\text { Combustion }\end{array}$ & EOR & 2009 & Operating \\
\hline Shengli & Sinopec & China & Coal & 0.04 & $\begin{array}{l}\text { Post- } \\
\text { Combustion }\end{array}$ & EOR & 2007 & Operating \\
\hline Mongstad & Statoil & Norway & Gas & 0.1 & $\begin{array}{l}\text { Post- } \\
\text { Combustion }\end{array}$ & Saline & 2012 & Operating \\
\hline Jingbian & Yanchang & China & Chemicals & 0.04 & N/A & EOR & 2012 & Operating \\
\hline Lula & Petrobas & Brazil & Gas Production & 0.7 & Gas Production & EOR & 2013 & Operating \\
\hline Shand & SaskPower & Canada & Coal & 0.043 & $\begin{array}{l}\text { Post- } \\
\text { Combustion }\end{array}$ & Vented & 2015 & Operating \\
\hline Tomakomai & JCCS & Japan & $\begin{array}{l}\text { Hydrogen } \\
\text { Production }\end{array}$ & 0.1 & $\begin{array}{l}\text { Post- } \\
\text { Combustion }\end{array}$ & Saline & 2016 & Operating \\
\hline
\end{tabular}

The pilot scale CCS facilities include use of the full range of capture technologies, including post-combustion, pre-combustion and oxyfuel. Further statistical analysis of this data can be undertaken in regard to the mean (mathematical average) and standard deviation (SD) for the pilot-scale plants with capacity levels according to the categories, which is provided in Table 6. This analysis highlights that there is a broad range of capacity levels adopted by pilot scale CCS facilities deploying post-combustion, whereas facilities adopting precombustion and oxy-fuel technologies have a narrow range of capacity levels.

Table 6. Further analysis of pilot-scale CCS facilities according to type of capture technology implemented. Source of data: Carbon Capture and Sequestration Technologies Group at Massachusetts Institute of Technology, USA (MIT, 2016).

\begin{tabular}{lllll}
\hline $\begin{array}{l}\text { Capture technology used on pilot scale CCS } \\
\text { facility (data in MW or Mt/yr) }\end{array}$ & Total capacity & Number of facilities (N) & Mean & Standard deviation (SD) \\
\hline Post-combustion (MW) & $135.60 \mathrm{MW}$ & 11 & $12.33 \mathrm{MW}$ & $14.63 \mathrm{MW}$ \\
Post-combustion (Mt/yr) & $1.34 \mathrm{Mt} / \mathrm{yr}$ & 8 & $0.17 \mathrm{Mt} / \mathrm{yr}$ & $0.21 \mathrm{Mt} / \mathrm{yr}$ \\
Pre-combustion (MW) & $34.00 \mathrm{MW}$ & 2 & $17.00 \mathrm{MW}$ & $3.00 \mathrm{MW}$ \\
Oxy-fuel (MW) & $125.00 \mathrm{MW}$ & 4 & $31.25 \mathrm{MW}$ & $2.17 \mathrm{MW}$ \\
\hline
\end{tabular}


Additional analysis can include calculating the number of pilot-scale CCS facilities commissioned per annum as well as the cumulative number of facilities $(\mathrm{N}=31)$. Consequently, Figure 8 provides the number of CCS facilities commissioned per annum alongside the cumulative data line. It can be observed that the peak years for new facilities to be commissioned were 2008, 2009 and $2012(\mathrm{~N}=5)$, followed by $2011(\mathrm{~N}=4)$, and $2013(\mathrm{~N}=3)$. In more recent years for the data available, which is from 2014 to 2016, the number of facilities was at a lower level $(\mathrm{N}=1)$.

Figure 8. Number of CCS facilities commissioned per annum along with the cumulative data. Source of data: Carbon Capture and Sequestration Technologies Group at Massachusetts Institute of Technology, USA (MIT, 2016).

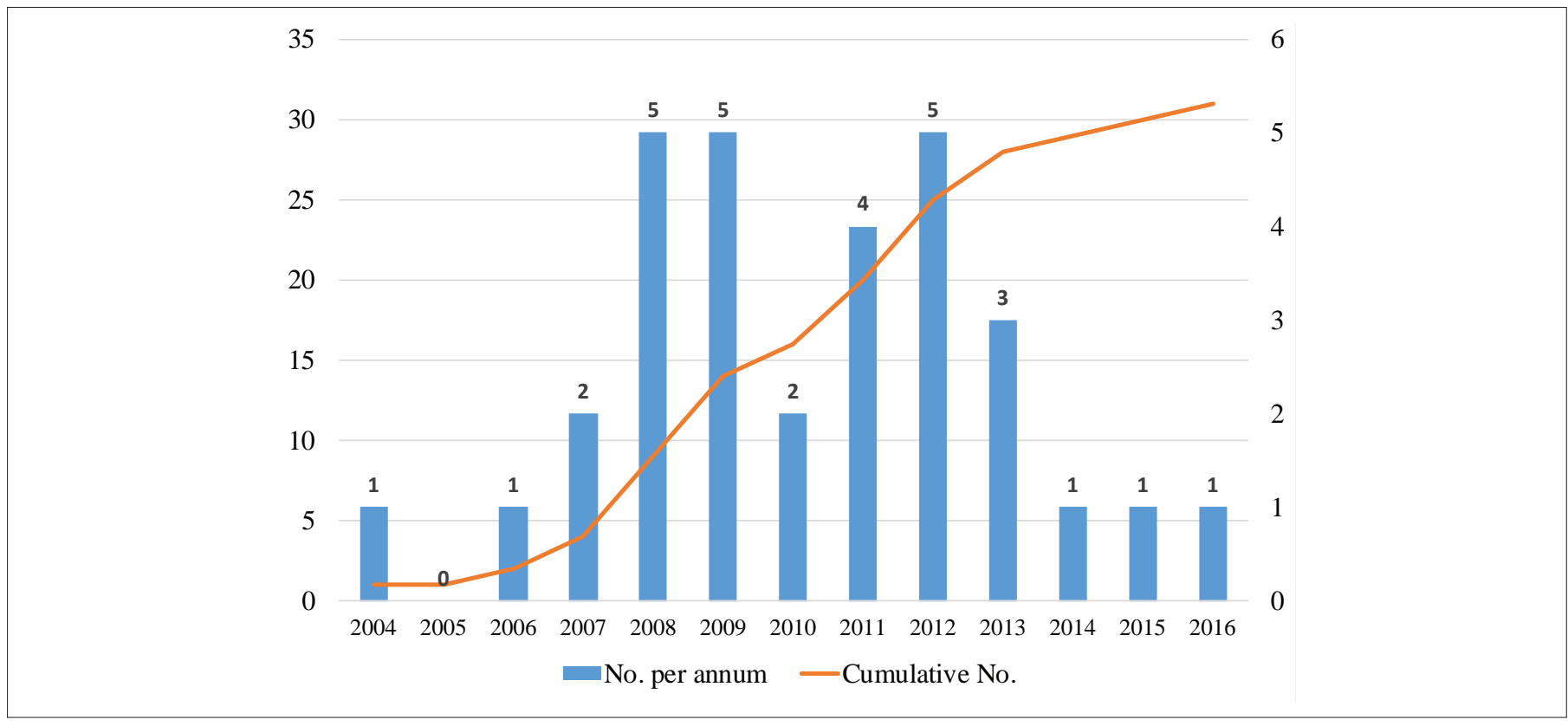

Further analysis can be carried out in regard to the countries where the pilot-scale facilities were commissioned and this is provided in Figure 9 (data provided as the percentage share of the total, $\mathrm{N}=31$ ). As can be observed, the countries with the greatest share of CCS fa- cilities with $16.1 \%(\mathrm{~N}=5)$ are USA and China. Germany has $9.7 \%$ $(\mathrm{N}=3)$. Spain, the Netherlands, UK, Australia, Canada, and Norway have 6.5\% $(\mathrm{N}=2)$, and Sweden, France, Italy, Brazil, Japan, and South Korea have $3.2 \%(\mathrm{~N}=1)$.

Figure 9. Geographical location (percentage) of CCS pilot-scale facilities commissioned. Source of data: Carbon Capture and Sequestration Technologies Group at Massachusetts Institute of Technology, USA (MIT, 2016).

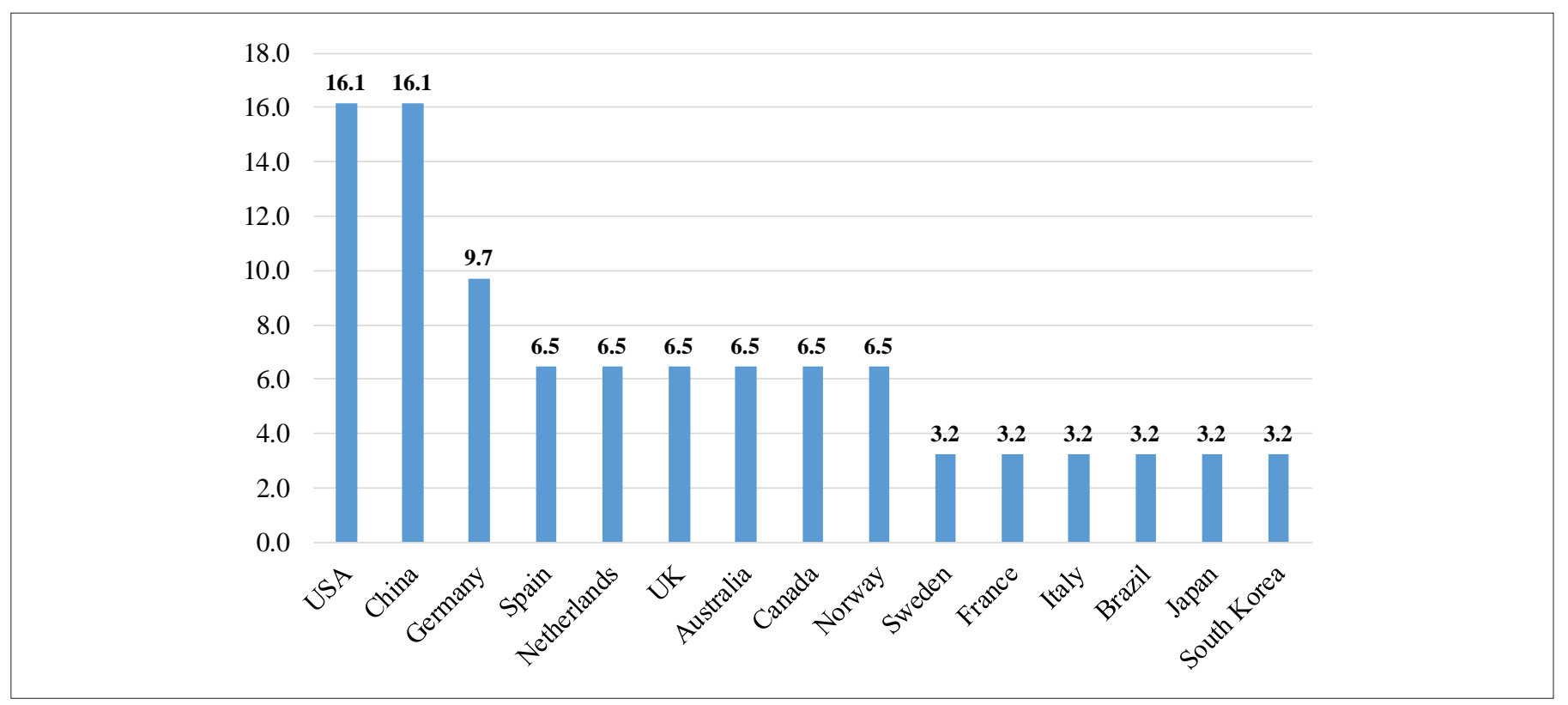




\section{CCS research agenda}

In order to inform future research directions, the following research agenda has been developed through considering the findings from this research study (see Table 7). The proposed research areas have been categorized according to being technology, economic, and policy \& regulation related as well as broader integrating type areas.

Table 7. CCS Research agenda

\begin{tabular}{|c|c|}
\hline Category & Proposed research areas \\
\hline $\begin{array}{l}\text { Technology related re- } \\
\text { search for CCS projects }\end{array}$ & $\begin{array}{l}\text { - Enhancement of membrane and solvent-based } \mathrm{CO}_{2} \text { capture systems along with the associated engineering and process im- } \\
\text { provements. } \\
\text { - Optimization of underpinning technologies to support post-combustion, pre-combustion and oxy-fuel capture systems. } \\
\text { - Simulation models to improve the understanding of long-term storage of } \mathrm{CO}_{2} \text { in geological formations. } \\
\text { - Life cycle analysis and system level analysis (e.g. system dynamics models) to consider environmental impact of technology } \\
\text { options across capture, transport and storage phases of CCS projects. }\end{array}$ \\
\hline $\begin{array}{l}\text { Economic related research } \\
\text { for CCS projects }\end{array}$ & $\begin{array}{l}\text { - Further comparative studies on the whole-life costs of CCS plants, building on existing models (such as levelized cost of } \\
\text { electricity models). } \\
\text { - } \quad \text { Role of government funding instruments (such as carbon taxes) to promote CCS technology adoption. } \\
\text { - } \quad \text { Cost reduction strategies for core CCS technologies. } \\
\text { Industrial supply chain initiatives to support supply side provision of CCS capabilities, including role of SMEs (small and } \\
\text { medium enterprises) on CCS projects. } \\
\text { Improved decision-making frameworks and cognitive processes for CCS project investments. }\end{array}$ \\
\hline $\begin{array}{l}\text { Policy \& regulation } \\
\text { related research for CCS } \\
\text { projects }\end{array}$ & $\begin{array}{l}\text { - Effectiveness of public engagement mechanisms to improve awareness of the societal benefits of CCS projects as well as the } \\
\text { associated health, safety and environmental considerations. } \\
\text { Policy instruments that support joint government and industry investment frameworks for long-term CCS options on electric } \\
\text { power generation and industrial process applications. } \\
\text { Multi-level frameworks that link international, national and local government level regulatory mechanisms and decision- } \\
\text { making (e.g. review and approval of CCS plant site selection decisions). }\end{array}$ \\
\hline $\begin{array}{l}\text { Integrating research ap- } \\
\text { proaches for CCS projects }\end{array}$ & $\begin{array}{l}\text { - Sharing of data and information on CCS cost reduction strategies through establishing CCS networks and partnerships. } \\
\text { - Stakeholder liaison and public engagement to raise the profile of CCS along with other climate change mitigation strategies. } \\
\text { - Multidisciplinary research programs drawing on technological and engineering disciplines as well as social and economic } \\
\text { areas that enable system level perspectives to be developed on CCS projects. }\end{array}$ \\
\hline
\end{tabular}

\section{Conclusions}

This paper has provided the findings and insights from the technoeconomic analysis of carbon capture and storage, which has focused on the adoption of CCS technologies as well as the sustainability of the process from an economic perspective. Implementation of CCS technologies is required as part of the global attempts to mitigate the deleterious impact that greenhouse gases (GHG) are having on the environment and the resulting climate change. Furthermore, it is recommended that CCS adoption will need to sit alongside other power generation sources such as renewables (e.g. solar, wind, and tidal) and next generation nuclear fission in conjunction with energy savings measures and the use of alternative fuel systems (such as electric vehicles, which is dependent on the electrical power having a low carbon penalty at the point of source generation). This can be viewed in the context of a need for a greater multiplicity of energy sources.

The level of investment into new CCS projects has been increasing dramatically over the last several years and this is a resulting in a significant increase in the level of global capacity for $\mathrm{CO}_{2}$ storage and this includes both EOR and geological storage mechanisms (with the former still be the largest share of capacity). This trend is set to increase along with increasing investment in CCS technologies across post-combustion, pre-combustion and oxy-fuel capture systems. Technology is also being rapidly developed to support specific CCS applications, such as for use in integrated gasification combined cycle (IGCC) applications, which offers significant potential to capture $\mathrm{CO}_{2}$ while having low penalties in terms of plant energy efficiency as well as capital and operational costs.

On the matter of policy determinants relating to investment into CCS technologies, it has been found that that the CCS decision factors with the highest impact are capture technology, storage technology, and cost reduction. Other factors having a moderate impact include investment decision, environmental assessment, regulatory framework, and site selection. Factors identified to have a low level impact include transportation system, public awareness, government funding, monitoring technology, and international collaboration. This highlights that CCS is still very much driven by the maturity and capabilities of the capture and storage technologies as well as the need to reduce the 
costs for implementing such technologies. Although other areas have the potential to impact CCS technology adoption, such as environmental and regulatory aspects and site selection.

In regard to the implementation of CCS technologies as part of pilot scale facilities, it has been found that post-combustion technology is the most common capture technology adopted when compared to pre-combustion and oxy-fuel capture systems. Furthermore, statistical analysis has highlighted that there is a broad range of capacity levels adopted by pilot scale CCS facilities deploying post-combustion, when compared to facilities adopting pre-combustion and oxy-fuel technologies, which have a narrow range of capacity levels. Nevertheless, and despite the challenges associated with CCS, there has been growth in CCS capacity up to the year 2017. The rate of growth in capacity highlights the increasing rate of adoption of CCS technologies along with a rapidly increasing level of global $\mathrm{CO}_{2}$ storage capacity. CCS pilot scale facilities have been commissioned in countries across the World and the current leaders in the field are USA and China.

Levelized cost of electricity (LCOE) is a useful numerical framework for assessing the lifetime costs for various power generation technologies, including assessing the case for CCS adoption. Although the addition of CCS to gas fired and coal fired plants does result in an LCOE cost premium being added, such systems appear to compare favorably to various renewable energy technologies, such as offshore wind and solar photovoltaics (PV power systems). Moreover, results from this research study based on a regression model on the adoption of CCS for combined cycle gas turbines (CCGT) have indicated that there is a trend for CCGT systems (both with and without CCS) to have lower costs. In this case, CCGT fitted with CCS is expected to have a lower LCOE in 2022, when compared to conventional CCGT without CCS in 2012. This trend indicates a potentially improving economic position for the adoption of CCS technology for the application of power generation via CCGT.

Future work is suggested to enable further detailed research on existing CCS projects and also projects under development. This includes case study investigation and use of appropriate quantitative methods, such as structural equation modelling, or analytic hierarchy process. Further research is also suggested on the development of innovative business models to support investment into CCS technologies as part of clean energy systems.

\section{References}

Anderson, S., \& Newell, R. (2004). Prospects for carbon capture and storage technologies. Annual Review of Environment and Resources, 29, 109-142. https://www.annualreviews.org/doi/abs/10.1146/annurev.energy.29.082703.145619

Anthony, E. J., \& Clough, P. T. (2019). Post-Combustion Carbon Capture and Storage in Industry. In CO2 Separation, Purification and Conversion to Chemicals and Fuels (pp. 39-53). Springer, Singapore. https://link.springer.com/chapter/10.1007/978-981-13-3296-8_4
Benson, S. M., \& Cole, D. R. (2008). CO2 sequestration in deep sedimentary formations. Elements, 4(5), 325-331. https://doi.org/10.2113/ gselements.4.5.325

Bui, M., Adjiman, C. S., Bardow, A., Anthony, E. J., Boston, A., Brown, S., ... \& Hallett, J. P. (2018). Carbon capture and storage (CCS): the way forward. Energy \& Environmental Science, 11(5), 1062-1176. https://doi.org/10.1039/C7EE02342A

Cornwall, W. (2015). Inside the Paris climate deal. Science, 350(6267), 1451-1451. https://doi.org/10.1126/science.350.6267.1451

Dos Santos, S. F., Borschiver, S., \& de Souza, V. (2014). Mapping sustainable structural dimensions for managing the Brazilian biodiesel supply chain. Journal of Technology Management and Innovation, 9(1), 27-43. https://doi.org/10.4067/S0718-27242014000100003

Figueroa, J. D., Fout, T., Plasynski, S., McIlvried, H., \& Srivastava, R. D. (2008). Advances in CO 2 capture technology-the US Department of Energy's Carbon Sequestration Program. International Journal of Greenhouse Gas Control, 2(1), 9-20. https://doi.org/10.1016/S17505836(07)00094-1

Gammer, D. Energy Technologies Institute (2016). Reducing the cost of CCS - Developments in Capture Plant Technology, Energy Technologies Institute, Retrieved: https://d2umxnkyjne36n.cloudfront.net/ insightReports/Capture-Plant-Insight.pdf?mtime=20160908134243

Gibbins, J., \& Chalmers, H. (2008). Carbon capture and storage. Energy Policy, 36(12), 4317-4322. https://doi.org/10.1016/j.enpol.2008.09.058

Gibson, R. B. (2006). Beyond the pillars: sustainability assessment as a framework for effective integration of social, economic and ecological considerations in significant decision-making. Journal of Environmental Assessment Policy and Management, 8(03), 259-280. https:// doi.org/10.1142/S1464333206002517

Gough, C. (2008). State of the art in carbon dioxide capture and storage in the UK: An experts' review. International Journal of Greenhouse Gas Control, 2(1), 155-168. https://doi.org/10.1016/S17505836(07)00073-4

Global CCS Institute (2016). The Global Status of CCS: Summary Report. Retrieved: http://hub.globalccsinstitute.com/sites/default/files/ publications/201158/global-status-ccs-2016-summary-report.pdf

Global CCS Institute (2017). Large Scale CCS Projects. Retrieved: https://www.globalccsinstitute.com/projects/large-scale-ccs-projects

Haszeldine, R. S. (2009). Carbon capture and storage: how green can black be?. Science, 325(5948), 1647-1652. https://doi.org/10.1126/ science. 1172246

Horlock, J. (1992). Combined Power Plants: Including Combined Cycle Gas Turbined CCGT Plants. Elsevier. 
International Energy Agency (2012). Energy Technology Perspectives 2012 - Pathways to a Clean Energy System (p. 345), Retrieved: https:// www.iea.org/publications/freepublications/publication/ETP2012_ free.pdf

International Energy Agency (2015). Carbon Capture and Storage: The solution for deep emissions reductions. Retrieved: https://www.iea. org/publications/freepublications/publication/CarbonCaptureandStorageThesolutionfordeepemissionsreductions.pdf

Intergovernmental Panel on Climate Change (2018). IPCC Special Report on Global Warming of $1.5^{\circ} \mathrm{C}$. Retrieved: https://unfccc.int/ topics/science/workstreams/cooperation-with-the-ipcc/ipcc-specialreport-on-global-warming-of-15-degc

Irlam, L. (2015). The costs of ccs and other low-carbon technologies - 2015 update. Global CCS Institute. Retrieved: https://hub.globalccsinstitute.com/sites/default/files/publications/195008/costs-ccs-otherlow-carbon-technologies-united-states-2015-update.pdf

Kanniche, M., Gros-Bonnivard, R., Jaud, P., Valle-Marcos, J., Amann, J. M., \& Bouallou, C. (2010). Pre-combustion, post-combustion and oxy-combustion in thermal power plant for CO2 capture. Applied Thermal Engineering, 30(1), 53-62. https://doi.org/10.1016/j.applthermaleng.2009.05.005

Kunze, C., \& Spliethoff, H. (2012). Assessment of oxy-fuel, pre-and post-combustion-based carbon capture for future IGCC plants. Applied Energy, 94, 109-116. https://doi.org/10.1016/j.apenergy.2012.01.013

Markusson, N., Kern, F., Watson, J., Arapostathis, S., Chalmers, H., Ghaleigh, N., ... \& Russell, S. (2012). A socio-technical framework for assessing the viability of carbon capture and storage technology. Technological Forecasting and Social Change, 79(5), 903-918. https:// doi.org/10.1016/j.techfore.2011.12.001

Massachusetts Institute of Technology (MIT). (2016). Carbon Capture Sequestration Project Database provided by the Carbon Capture and Sequestration Technologies Group at MIT (USA). Retrieved: https://sequestration.mit.edu/tools/projects/index_pilots.html

Metz, B., Davidson, O., De Coninck, H. C., Loos, M., \& Meyer, L. A. (2005). IPCC, 2005: IPCC special report on carbon dioxide capture and storage. Prepared by Working Group III of the Intergovernmental Panel on Climate Change. Cambridge, United Kingdom and New York, NY, USA, 442.

Nakaten, N., Schlüter, R., Azzam, R., \& Kempka, T. (2014). Development of a techno-economic model for dynamic calculation of cost of electricity, energy demand and $\mathrm{CO} 2$ emissions of an integrated UCG-CCS process. Energy, 66, 779-790. https://doi.org/10.1016/j. energy.2014.01.014
Philbin, S. P. (2013). Emerging requirements for technology management: a sector-based scenario planning approach. Journal of Technology Management and Innovation, 8(3), 34-44. http://dx.doi. org/10.4067/S0718-27242013000400004

Pires, J. C. M., Martins, F. G., Alvim-Ferraz, M. C. M., \& Simões, M. (2011). Recent developments on carbon capture and storage: an overview. Chemical Engineering Research and Design, 89(9), 1446-1460. https://doi.org/10.1016/j.cherd.2011.01.028

Selma, L., Seigo, O., Dohle, S., \& Siegrist, M. (2014). Public perception of carbon capture and storage (CCS): a review. Renewable and Sustainable Energy Reviews, 38, 848-863. https://doi.org/10.1016/j. rser.2014.07.017

Schwarz, J., Beloff, B., \& Beaver, E. (2002). Use sustainability metrics to guide decision-making. Chemical Engineering Progress, 98(7), 5863. https://pdfs.semanticscholar.org/b29a/e01b85d8ef7c72150a7e938823c02a4ee685.pdf

Short, W., Packey, D. J., \& Holt, T. (2005). A manual for the economic evaluation of energy efficiency and renewable energy technologies. Hawaii: University Press of the Pacific. https://www.osti.gov/ biblio/35391

Tan, Y., Nookuea, W., Li, H., Thorin, E., \& Yan, J. (2016). Property impacts on Carbon Capture and Storage (CCS) processes: A review. Energy Conversion and Management, 118, 204-222. https://doi. org/10.1016/j.enconman.2016.03.079

United States Department of Energy (2019). US Energy Department Investments in Innovative Carbon Capture Projects, Retrieved: https:// energy.gov/energy-department-investments-innovative-carbon-capture-projects

United States Energy Information Administration (2018). Levelized Cost and Levelized Avoided Cost of New Generation Resources in the Annual Energy Outlook 2018 (p. 6), Retrieved: https://www.eia.gov/ outlooks/aeo/pdf/electricity_generation.pdf

Yang, H., Wei, Z., \& Chengzhi, L. (2009). Optimal design and techno-economic analysis of a hybrid solar-wind power generation system. Applied Energy, 86(2), 163-169. https://doi.org/10.1016/j.apenergy.2008.03.008

Zoulias, E. I., \& Lymberopoulos, N. (2007). Techno-economic analysis of the integration of hydrogen energy technologies in renewable energy-based stand-alone power systems. Renewable Energy, 32(4), 680-696. https://doi.org/10.1016/j.renene.2006.02.005 
